\title{
An Assessment About The History of The Turkish Veterinary Medical Association Chamber of Veterinarian for Afyonkarahisar
}

\author{
Emine TÜRKMENOĞLU* \\ Yozgat Bozok University, Faculty of Veterinary Medicine, Department of Veterinary History and Deontology, Sorgun/Yozgat, Turkey
}

\begin{abstract}
The first chambers of veterinarian became operative in Turkey after the enactment of Law number 6343 in 1954. Chambers of veterinarian are tasked with ensuring that the relevant professional legislation is duly applied. This study has been carried out to provide information about the historical development of the Turkish Veterinary Medical Association Chamber of Veterinarian for Afyonkarahisar Region (Afyonkarahisar CV). The study material is comprised of first hand documents obtained from the Afyonkarahisar CV Archive and the Turkish Veterinary Medical Association Archive and the relevant material has been assessed with the retrospective method used in historical research. Afyonkarahisar CV became operable in 1968. During its historical development process, the chamber has held meetings in search of solutions for professional problems, decision making and organized various training programs. It has been concluded that Afyonkarahisar CV is responsible for positive contributions to the professional development of veterinary medicine in Turkey.
\end{abstract}

Keywords: The Chamber of Veterinarian for Afyonkarahisar, The Turkish Veterinary Medical Association, History of Veterinary Medicine.

Türk Veteriner Hekimleri Birliği Afyonkarahisar Veteriner Hekimler Odasının Tarihi Hakkında Bir Değerlendirme

ÖZ

Türkiye'de ilk veteriner hekim odaları 6343 sayll Kanunun yürürlüğe girmesinden sonra 1954'te faaliyete geçirildi . Veteriner hekim odaları meslekle ilgili mevzuatın gereği gibi uygulanmasını sağlamakla yükümlüdürler. Bu çalışma Türk Veteriner Hekimleri Birliği Afyonkarahisar Veteriner Hekimler Odası (Afyonkarahisar VHO)'nın tarihi gelişimi hakkında bilgi vermek amacı ile yapıldı. Çalışmanın materyalini Afyonkarahisar VHO Arşivi ve Türk Veteriner Hekimleri Birliği Arşivinden elde edilen ilk elden belgeler oluşturdu ve söz konusu materyal, tarih araştırmalarında kullanılan retrospektif yöntemle değerlendirildi. Afyonkarahisar VHO'nun 1968'de faaliyete geçtiği saptandı. Tarihi gelişim süreci içerisinde oda tarafindan mesleki sorunlara çözüm yollarının arandığı toplantıların kararlaştırıldığı ve çeşitli eğitim programlarının düzenlendiği belirlendi. Afyonkarahisar VHO'nun Türkiye'de veteriner hekimliği mesleğinin gelişimine olumlu katkılarda bulunduğu sonucuna varıldı.

Anahtar Kelimeler: Afyonkarahisar Veteriner Hekimler Odas1, Türk Veteriner Hekimleri Birliği, Veteriner Hekimliği Tarihi.

\footnotetext{
To cite this article: Türkmenoğlu E. An Assessment About The History of The Turkish Veterinary Medical Association Chamber of Veterinarian for Afyonkarabisar. Kocatepe Vet J. (2019) 12(2):185-192. 


\section{GİRİŞ}

Türk Veteriner Hekimleri Birliği (TVHB) 6343 sayılı Kanunla kurulmuş olan ve veteriner hekimliği mesleğinin Türkiye çıkarlarına en faydalı biçimde uygulanmasını sağlama, veteriner hekimlerin maddi ve manevi hak ve yararlarını koruma gibi görevleri bulunan kamu kurumu niteliğinde bir meslek kuruluşudur $^{1}$. TVHB'yi oluşturan organlardan biri olan veteriner hekim odalarının ilk olanlarına 1954'te işlerlik kazandırıldı ${ }^{2}$. Veteriner hekim odaları, sınırları içinde en az 30 veteriner hekim bulunan illerde ya da bölgelerde kurulmaktadır. Odalar sahip oldukları genel kurul, yönetim kurulu, denetleme kurulu ve haysiyet divanı olmak üzere dört organ aracıllı̆ıyla meslekle ilgili mevzuatın gereği gibi uygulanmasını sağlamaya yönelik çalışmalarda bulunmaktadır ${ }^{3}$.

Günümüzde Türkiye'de faaliyet gösteren 56 veteriner hekim odasından sekizinin Ege Bölgesinde bulunduğu ve TVHB İzmir Veteriner Hekimler Odası (İzmir VHO)'ndan (1954) sonra TVHB Afyonkarahisar Veteriner Hekimler Odası (Afyonkarahisar VHO)nın bölgede kurulan ikinci oda olduğu belirlendi

Türkiye'deki veteriner hekim odalarının tarihi konusunda TVHB Samsun-Sinop Bölgesi Veteriner Hekimler Odası (Samsun-Sinop VHO) (Sanal ve Melikoğlu Gölcü 2014) ve TVHB Kars Bölgesi Veteriner Hekimleri Odası (Kars VHO) (Kuzlltepe 2017) hakkinda birer adet bilimsel yayına rastland. Yapilan incelemelerde Afyonkarahisar VHO'nun 1968-1975 y1llarına ait herhangi bir evraka rastlanamad1. Bu araştırma Afyonkarahisar VHO'nun tarihsel gelişimi hakkında bilgi vermek amacı ile yapild1.

\section{MATERYAL VE METOT}

Çalışmanın materyalini Resmi Gazete Arşivi, TVHB Arşivi ve Afyonkarahisar VHO Arşivinden sağlanan ilk elden belgeler oluşturdu. Ayrica konuyla ilgili literatürden faydalanıldı. Orijinal belgelerin künyeleri dipnotlar halinde gösterildi. Mevcut materyal tarih araştırmalarında kullanılan retrospektif yöntem ile değerlendirildi.

\section{BULGULAR}

Afyonkarahisar VHO'nun 1968'de kurulduğu ve ilk oda yönetim kurulu başkanının Mehmet Eroğlu olduğu (1968-1969) belirlendi. Daha sonra sıras1 ile Yakup Hamza Çebi (1969-1970), Mehmet Eroğlu (1970-1971, 1971-1972), Abdullah Kardan (19721973), Süleyman Özkan (1973-1974) ve Sedat Öncel'in (1974-1975, 1975-1976) odaya başkanlık yaptıkları saptand15,6. Günümüze kadar seçilmiş 34

${ }^{1}$ 09/03/ 1954 tarihli ve 6343 sayılı Veteriner Hekimliği Mesleğinin İcrasına, Türk Veteriner Hekimleri Birliği ile Odalarının Teşekkül Tarzına ve Göreceği İşlere

Dair Kanun, 18/03/1954 tarihli ve 8661 sayılı Resmî Gazete.

${ }^{2}$ TVHB Arșiv Belgeleri (1954-2018).

${ }^{3}$ Türk Veteriner Hekimleri Birliği Hizmetlerinin Yürütülmesine İlişkin

Uygulama Yönetmeliği, 13/09/2006 tarihli 26288 sayılı Resmi Gazete.

${ }^{4}$ Bkz: Dipnot 2.

${ }^{5} 23 / 01 / 1985$ tarih ve 73/300 nolu gelen evrak. Afyonkarahisar VHO Arșivi.

${ }^{6} 31 / 01 / 1985$ tarih ve 19 nolu giden evrak. Afyonkarahisar VHO Arşivi. oda yönetim kurulu başkanı arasında hiç kadın veteriner hekimin bulunmadiğ1 ve toplam yönetim kurulu üyeleri arasında bir kadın üyenin sadece bir dönem yer aldığı ve odanın diğer organlarında hiç kadın bulunmadığı belirlendi. Afyonkarahisar VHO organlarına seçilmiş veteriner hekimlerin isimleri Tablo 1-4'te sunuldu?

Resmi evraklarda odanın isminin 1976'dan itibaren "Afyon Bölgesi Veteriner Hekimler Odası" biçiminde yazıldığ ${ }^{8}$ ve 1977 'de odanın sorumluluk alanında Afyonkarahisar, Antalya, Burdur, Isparta ve Uşak illerinin bulunduğu tespit edildi ${ }^{9}$. Antalya'nın 1978, Burdur'un 199210, Isparta'nın 19. ile 20. dönem genel kurulları arasındaki süreçte ${ }^{11}$, Uşak'in ise 1998'de Afyonkarahisar VHO'dan ayrildı̆g1'12,13 ve bundan sonra odanin isminin "Afyon Veteriner Hekimler Odas1" biçiminde, 2006'dan itibaren ise "Afyonkarahisar Veteriner Hekimler Odası" biçiminde yazıldığı tespit edildi ${ }^{14}$.

Antalya'da 30 Eylül 1976'da gerçekleşen genel kurul sonrasında Antalya Veteriner İşleri Baş Müdürü Sedat Öncel'den ${ }^{15}$ boşalan oda başkanlığına Afyonkarahisar Veteriner İşleri Müdürü Necdet Demir'in gelmesinden sonra oda adresinin Afyonkarahisar Veteriner İşleri Müdürlügü olduğu'16 ve 1979 'da söz konusu müdürlüğün bir odasında il dişından gelen oda üyelerinin barınması için bir misafirhane kurulduğu saptand $1^{17},{ }^{18}$. Veteriner Bölge Sağlik Kontrol Laboratuvar Müdürlügünün yeni binasina taşınmasından sonra eski binasının uygun olan odalarından bazılarının Afyonkarahisar VHO'ya lokal ve misafirhane olarak ayrildı̆g belirlendi ${ }^{19}$. Söz konusu misafirhanenin 1985 'te kapatıldığ ${ }^{20}$ ve 2005 yılında oda için Vakıflar Müdürlügünde bir büro kiralanmasina karar verildiği ${ }^{21}$ ve oda adresinin 3 . Vakıf İş Hanı kat: 6, no: 42 olduğu saptand1 ${ }^{22}$. Günümüzde ise Afyonkarahisar VHO'nun 2013'te satın alınan Çetinkaya mahallesi Uydukent İş Merkezindeki 22 no’lu dairede faaliyet gösterdiği belirlendi ${ }^{23}, 24$.

\footnotetext{
71976-2016 genel kurul seçim tutanakları. Afyonkarahisar VHO Arşivi. ${ }^{8}$ Afyonkarahisar VHO Arşivi.

${ }^{9}$ 1977-1978 dönemi yönetim kurulu çalışma raporu. Afyonkarahisar VHO Arşivi. ${ }^{10}$ Bkz: Dipnot 2.

${ }^{11} 1992-1994$ dönemi yönetim kurulu çalışma raporu. Afyonkarahisar VHO Arşivi.

${ }^{12} 23 / 03 / 1998$ tarih ve 20nolu yönetim kurulu kararı. Afyonkarahisar VHO Arşivi.

${ }^{13} 21 / 08 / 1998$ tarih ve 30 nolu yönetim kurulu kararı. Afyonkarahisar VHO Arşivi.

${ }^{14}$ 27/09/2006 tarihli genel kurul seçim tutanağı. Afyonkarahisar VHO Arşivi.

${ }^{15}$ 1976-1977 dönemi yönetim kurulu çalışma raporu. Afyonkarahisar VHO Arşivi.

${ }^{16}$ Bkz: dipnot 8

${ }^{17} 22 / 01 / 1979$ tarih ve 8 nolu yönetim kurulu kararı. Afyonkarahisar VHO Arşivi.

${ }^{18} 12 / 03 / 1979$ tarih ve 11 nolu yönetim kurulu kararı. Afyonkarahisar VHO Arşivi.

${ }^{19}$ 1980-1981 dönemi yönetim kurulu çalışma raporu. Afyonkarahisar VHO

Arşivi.
${ }_{120} 13 / 05 / 1985$ tarih ve 9 nolu yönetim kurulu kararı. Afyonkarahisar VHO Arşivi.

${ }^{21} 15 / 02 / 2005$ tarih ve 35 nolu yönetim kurulu kararı. Afyonkarahisar VHO Arşivi.

${ }^{22} 03 / 11 / 2013$ tarihli yönetim kurulu kararı. Afyonkarahisar VHO Arșivi.

${ }^{23}$ 27/09/2013 tarihli yönetim kurulu kararı. Afyonkarahisar VHO Arşivi.

${ }^{24}$ 30/09/2013 tarihli yönetim kurulu kararı. Afyonkarahisar VHO Arşivi.
} 


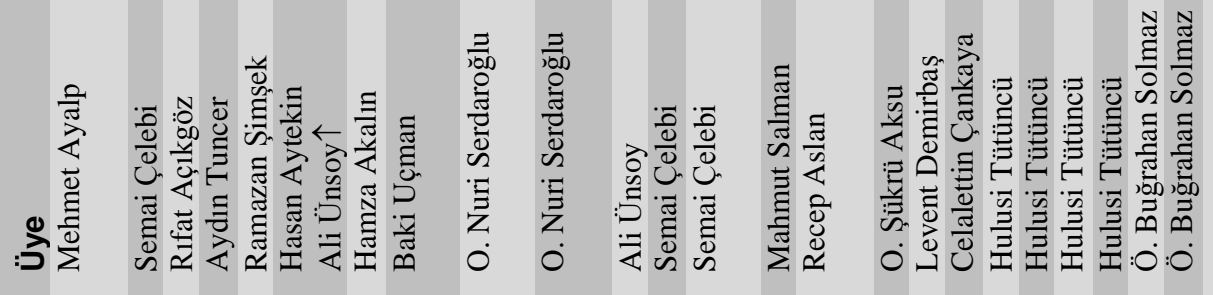

에

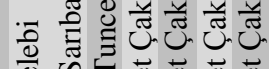

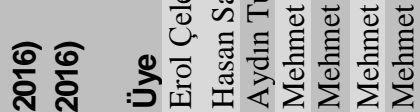

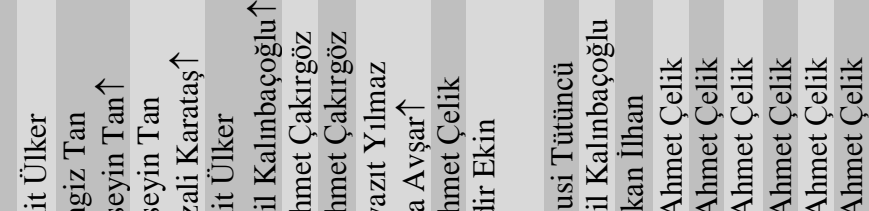

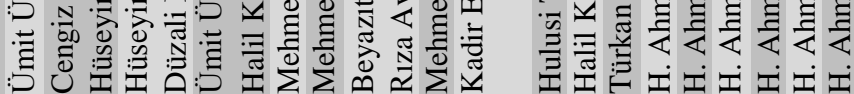

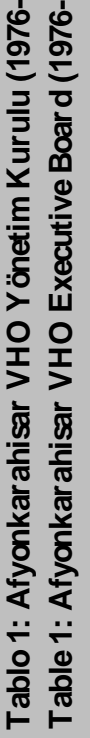

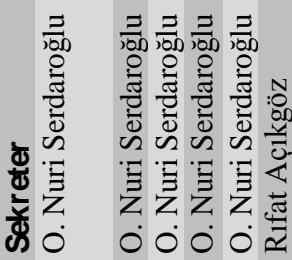

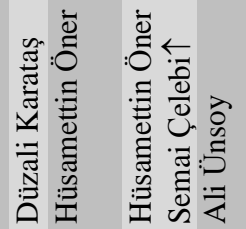

这窇

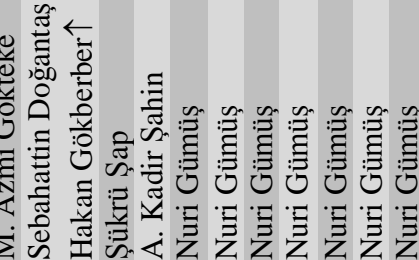

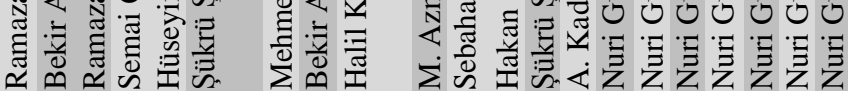

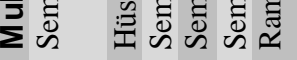

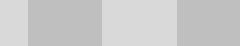




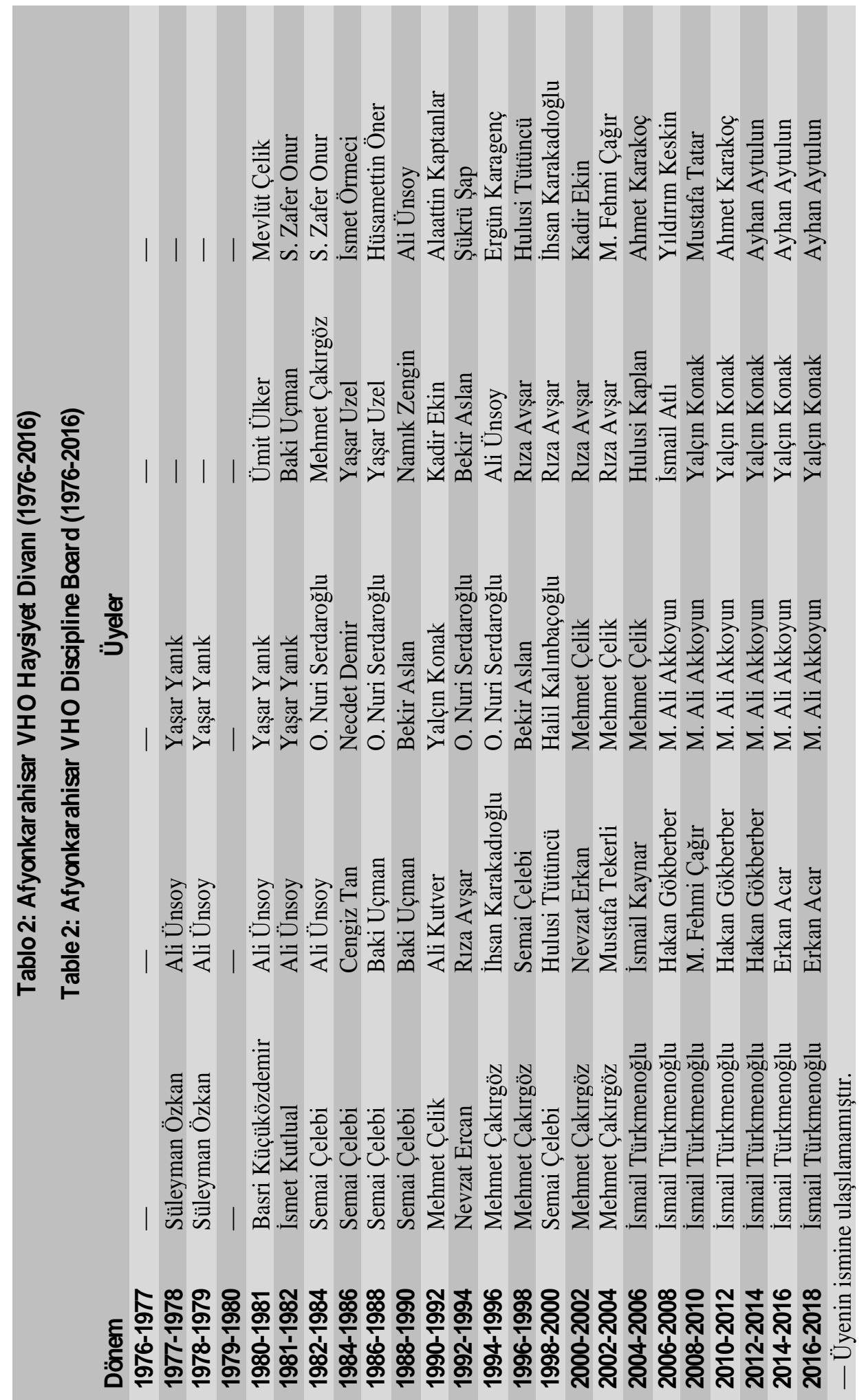




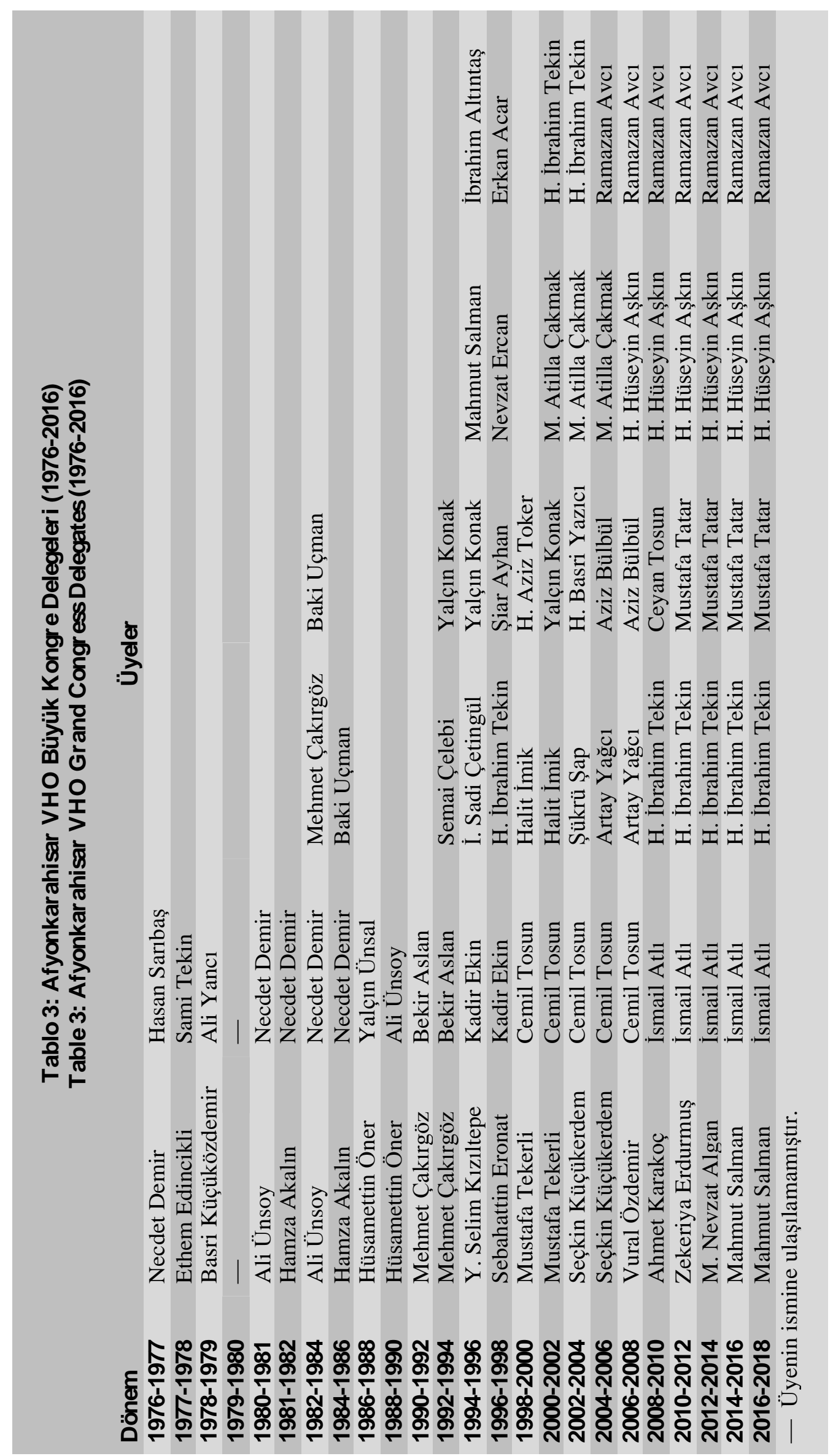


Tablo 4: Afyonkarahisar VHO Denetleme Kurulu (1976-2018)

Table 4: Afyonkarahisar VHO Inspection Board (1976-2018)

\begin{tabular}{|c|c|c|}
\hline Dönem & \multicolumn{2}{|c|}{ Üyeler } \\
\hline 1976-1977 & - & - \\
\hline 1977-1978 & Baki Uçman & Muhsin Uysal \\
\hline 1978-1979 & Baki Uçman & Muhsin Uysal \\
\hline 1979-1980 & - & - \\
\hline 1980-1981 & Baki Uçman & Hamza Akalın \\
\hline 1981-1982 & Baki Uçman & Hamza Akalın \\
\hline 1982-1984 & Baki Uçman & Mehmet Çakırgöz \\
\hline 1984-1986 & Baki Uçman & Mehmet Çakırgöz \\
\hline 1986-1988 & Semai Çelebi & Hüseyin Tan \\
\hline 1988-1990 & Bekir Aslan & Halil Kalınbaçoğlu \\
\hline 1990-1992 & Hakan Boyar & Halil Kalınbaçoğlu \\
\hline 1992-1994 & O. Şükrü Aksu & Erol Ünsoy \\
\hline 1994-1996 & Sabahattin Doğantaş & Ali Ünsoy \\
\hline 1996-1998 & Hakan Gökberber & Ahmet Karakoç \\
\hline 1998-2000 & Hakan Karakoç & Azmi Gökteke \\
\hline 2000-2002 & Ahmet Karakoç & Ali Kutver \\
\hline 2002-2004 & Ahmet Karakoç & Ümit Dağdeviren \\
\hline 2004-2006 & Turgut Çivri & A. Kadir Şahan \\
\hline 2006-2008 & Zafer Avcı & A. Kadir Şahan \\
\hline 2008-2010 & Zafer Avcı & A. Kadir Şahan \\
\hline 2010-2012 & Zafer Avcı & A. Kadir Şahan \\
\hline 2012-2014 & Zafer Avcı & A. Kadir Şahan \\
\hline 2014-2016 & Numan Altıntas & Mustafa Aslan \\
\hline 2016-2018 & Numan Altıntaş & Mustafa Aslan \\
\hline
\end{tabular}

05 Ağustos 1983'te yayınlanan 68 sayll Kanun Hükmünde Kararname (KHK) ${ }^{25}$ ile veteriner hekim odalarının genel kurullarının 31 Ekim 1983 tarihine kadar yapılması hükme bağlanırken Sıkı Yönetim Koordinasyon Kurulu karar1 ile ${ }^{26}$ bu maddenin işletilmesinin durdurulduğu ve 16 Eylül 1983'te yayınlanan 86 sayll $\mathrm{KHK}^{27}$ le veteriner hekim odalarının genel kurullarının 01 Aralık 1983'ten itibaren üç ay içerisinde yapılmasının hükme bağlandığ1 saptand. Yukarıdaki nedenlerle Afyonkarahisar VHO'nun her yıl Eylül ayında gerçekleştirdiği olağan genel kurulun 1983'te yapılmadığ1 22 Ocak 1984'te yapıldığı belirlendi28.

\footnotetext{
25 9/3/1954 Tarih ve 6343 Sayılı Veteriner Hekimliği Mesleğinin İcrasına, Veteriner Hekimleri Birliği ile Odalarının Teşekkül Tarzına ve Göreceği İșlere Dair Kanunun Bazı Maddelerinin Değiștirilmesi ve Bu Kanuna Bazı Maddeler Eklenmesi Hakkında 1/6/1983 Tarihli ve 68 Sayılı Kanun Hükmünde Kararname.05/08/1983 tarih ve18126 sayılı Resmî Gazete.

${ }^{26}$ TVHB 30. büyük kongre tutanağı (1984). TVHB Arşivi.

27 9/3/1954 Tarih ve 6343 Sayılı Veteriner Hekimliği Mesleğinin İcrasına, Veteriner Hekimleri Birliği ile Odalarının Teșekkül Tarzına ve Göreceği İșlere Dair Kanunun Bazı Maddelerinin Değistirilmesi ve Bu Kanuna Bazı Maddeler Eklenmesi Hakkında 1/6/1983 Tarihli ve 68 Sayılı Kanun Hükmünde Kararnamenin Bazı Hükümleri ile 6343 Sayılı Kanun'un Bazı Hükümlerinin Değisstirilmesine Dair 6/9/1983 Tarihli 86 Sayılı Kanun Hükmünde Kararname. 16.09.1983 tarih ve 18167 sayılı Resmî Gazete.

28 1982-1984 dönemi yönetim kurulu çalıșma raporu. Afyonkarahisar VHO Arșivi.
}

Ayrıca mevzuatta yapılan değişiklikle ${ }^{29}$ odaların olağan genel kurullarının 1984'ten itibaren iki yılda bir yapılmaya başlandığı tespit edildi. Kamuda çalışan veteriner hekimlerin odaya üye olma mecburiyetinin 68 sayılı KHK 30ile kaldırlmasının hemen ardindan Afyonkarahisar VHO'nun üye sayisinın 63'den 49'a düştüğü tespit edildi ${ }^{31}$. Odaya kayıtlı üye sayısının 18 Temmuz 2018 tarihi itibarı ile 431 olduğu belirlendi ${ }^{32}$. Afyonkarahisar VHO'nun, ilaç satıșı konusunda üyeleri arasındaki haksız rekabeti önlemek amacı ile Ocak 2003'te Afyonkarahisar Eczacilar Odas1 Başkanlığ1 ile birlikte içeriğini; her iki odanın da ilaç satış1 konusunda ticari ahlak ve meslek etiği çerçevesinde haksız rekabeti önleyici tedbirleri alması, üyelerden protokolü uygulayacaklarına dair imza alınmas1; üyelerin aylık olarak belirlenecek fiyat listesine uyması ve listenin altında ücret alanlara yaptırım uygulanmasının oluşturduğu bir protokol

29 9/3/1954 Tarih ve 6343 Sayılı Veteriner Hekimliği Mesleğinin İcrasına, Veteriner Hekimleri Birliği ile Odalarının Teşekkül Tarzına ve Göreceği İşlere Dair Kanunun Bazı Maddelerinin Değiştirilmesi ve bu Kanuna Bazı Maddeler Eklenmesi Hakkında 1/6/1983 Tarihli ve 68 Sayılı Kanun Hükmünde Kararnamenin Bazı Hükümleri ile 6343 Sayılı Kanun'un Bazı Hükümlerinin Değiştirilmesine Dair 6/9/1983 Tarihli 86 Sayılı Kanun Hükmünde Kararnamenin Değiştirilerek Kabulü Hakkında Kanun (2993 Sayılı Kanun).07.04. 1984 tarih ve 18365 sayılı Resmî Gazete.

\footnotetext{
${ }^{30}$ Bkz: dipnot: 25

${ }^{31}$ Bkz: dipnot 28 .

32 18/07/2018 tarihli oda üye kayıt listesi. Afyonkarahisar VHO Arşivi.
} 
düzenledikleri tespit edildi33. Protokol çerçevesinde eczane ve veteriner hekim muayenehanelerini denetlemek için Afyonkarahisar VHO yönetim kurulundan da iki üyenin görevlendirildiği bir komisyonun oluşturulduğ ${ }^{34}$ ancak Rekabet Kurulunun odaya yapmiş olduğu tebligat ile söz konusu ilaç fiyat tespit listelerinin uygulamadan kaldırildığ1 saptand ${ }^{35}$.

Afyonkarahisar VHO'nun Merkez Konseyden, diğer odalardan ve çeşitli yerlerden gelen yazıları üyelerine ileterek çeşitli konularda onların görüş ve düşüncelerini aldığ $1^{36}$ ve odanın da gerekli zaman ve konularda Bakanlık ve Merkez Konseye görüş bildirdiği saptand1 ${ }^{37},{ }^{38}$. Pek çok dönemde (1977-1992) odaya gelir sağlamak amac1 ile bağış makbuzları bastırıldığ1 belirlendi ${ }^{39} .6343$ sayılı Kanun'un 18. Maddesi, 2993 sayllı Kanun'un 19. Maddesi40 ile yürürlükten kaldırılana kadar ikinci görev almak için odaya bașvuran veteriner hekimlerin onay ișlemlerinin yapıldığ1 tespit edildi ${ }^{41},{ }^{42},{ }^{43}$. Odada rutin olarak; üyelerin kayıt ve nakil işlemlerinin yapıldı̆̆ı, asgari ücret tarifnamesinin düzenlendiği ve üyelerle mesleki sorunların görüşülüp tartışıldığı toplantıların kararlaştırıldığı, odanın, il meclis toplantılarında temsil edildiği, günün ve konunun gerektirdiği durumlarda dönemin ilgili siyasi ve mesleki şahıslarına tebrik ya da konu ile ilgilenilmesi hususunda telgraflar çekildiği, yazılar yazıldığ1 ve veteriner hekimliğinin kuruluş y1l dönümünde ve 2000 y1lından itibaren Dünya Veteriner Hekimler gününde üyelerin aileleri ile birlikte katıldıkları kutlama programları düzenlendiği saptand $1^{44}, 45$.

Afyonkarahisar VHO tarihinden tespit edilen baz1 önemli faaliyetler; müsteşarlık seviyesinde yeni bir kuruluşta toplanma talebinin devlet büyüklerine telgrafla pek çok kez iletilmesi (1979-1980 dönemi) ${ }^{46}$, Merkez Konseye Veteriner Hekimler Yüksek Danışma Kurulunun kurulması önerisinin sunulması (1980-1981 dönemi4), üyelerle daha iyi iletişim kurabilmek için Burdur, Isparta ve Uşak illerinde birer temsilci görevlendirilmesi (1988-1990 dönemi) ${ }^{48}$, devlet büyüklerine Hayvancılık Bakanlığının kurulması için telgraflar çekilmesi (1990-1992

\footnotetext{
33 21/01/2003 tarih ve 7 nolu yönetim kurulu kararı. Afyonkarahisar VHO Arșivi. ${ }^{34}$ 27/01/2003 tarih ve 8 nolu yönetim kurulu kararı. Afyonkarahisar VHO Arşivi. $3503 / 11 / 2003$ tarih ve 17 nolu yönetim kurulu kararı. Afyonkarahisar VHO Arşivi.

${ }^{36}$ 1977-1981 yönetim kurulu çalıșma raporları. Afyonkarahisar VHO Arsivi.

${ }^{37}$ 08/03/1991 tarih ve 22 nolu yönetim kurulu kararı. Afyonkarahisar VHO Arşivi.

${ }^{38}$ 07/03/2007 tarih ve 756 sayılı gelen evrak. TVHB Arșivi.

39 1977-1992 yönetim kurulu çalıșma raporları. Afyonkarahisar VHO Arșivi.

${ }^{40}$ Bkz: dipnot 29

${ }^{41}$ 05/10/1978 tarih ve 3 nolu yönetim kurulu kararı. Afyonkarahisar VHO Arşivi.

${ }^{42}$ 20/11/1980 tarih ve 5 nolu yönetim kurulu kararı. Afyonkarahisar VHO Arşivi.

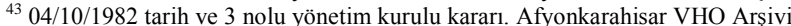

${ }^{44}$ 1976-2017 yönetim kurulu karar defterleri. Afyonkarahisar VHO Arșivi.

${ }^{45} 1976-2000$ yönetim kurulu çalıșma raporları, 24/09/1977, 05/10/1078,

27/09/1980, 19/09/1981, 18/09/1982; 22/01/1984, 23/09/1990, 20/09/1992,

$25 / 09 / 1994,29 / 09 / 1996$ ve $01 / 10 / 2000$ tarihli genel kurul belgeleri.

Afyonkarahisar VHO Arșivi.

${ }^{46}$ 1979-1980 dönemi yönetim kurulu çalışma raporu, 27/09/1980 tarihli genel kurul belgeleri. Afyonkarahisar VHO Arşivi.

${ }^{47}$ 1980-1981 dönemi yönetim kurulu çalışma raporu, 19/09/1981 tarihli genel kurul belgeleri. Afyonkarahisar VHO Arsivi.

${ }^{48}$ 1988-1990 dönemi yönetim kurulu çalıșma raporu, 23/09/1990 tarihli genel kurul belgeleri. Afyonkarahisar VHO Arşivi.
}

dönemi) ${ }^{49}$, Hayvancılık ve Su Ürünleri Müsteşarlığ1 kurulması talebinin devlet büyüklerine iletilmesi, dönemin Tarım ve Köy İşleri Bakanının ziyaret edilerek (16/03/1996) mesleki sorunların dile getirilmesi (1994-1996 dönemi) ${ }^{50}$, çeșitli tarihlerde suni tohumlama kurslar1 (4-8/10/200451, 24$28 / 07 / 2006^{52}$,) akredite veteriner hekim kurslar1 (11$13 / 03 / 2006,18-20 / 03 / 2006)^{53}$ ve hizmet içi eğitim kurslar1 düzenlenmesi $\left(18 / 11 / 2011^{54}\right.$, 19$\left.21 / 12 / 2011^{55}, 14-15 / 06 / 2012^{56}, \quad 23-24 / 12 / 2012^{57}\right)$ olarak tespit edildi.

Afyonkarahisar VHO'da değerlendirilen toplam beş disiplin vakasina rastland1 ${ }^{58},{ }^{59},{ }^{60,61}$ ve odanın1976'dan günümüze kadar herhangi bir yayın organının bulunmadığ1 belirlendi 62 .

\section{TARTIŞMA VE SONUÇ}

TVHB'nin tarihinin incelendiği bir araştırmada (Melikoğlu ve Kızıltepe 2008) TVHB arşivinin çok yetersiz olduğunun; belirlendiği benzer şekilde bu çalıșmada da hem TVHB Arşivi hem de Afyonkarahisar VHO Arşivinde oda ile ilgili 19681975 yıllarına ait bir evraka rastlanılmadığı, bu durumun ise söz konusu arşivler açısından bir eksiklik olduğu dolayısı ile daha düzenli ve tam bir arşivin tutulması gerektiği ileri sürülebilir.

Samsun-Sinop VHO'da seçilmiş (1969-2012) toplam 32 (Sanal ve Melikoğlu Gölcü 2014) ve Kars VHO’da seçilmiş (1989-2017) toplam 15 oda yönetim kurulu başkanı (Kızıltepe 2017) arasında hiç kadın veteriner hekimin bulunmadığ1 benzer şekilde Afyonkarahisar VHO' da da seçilmiş (1968-2016) 34 başkan arasında hiç kadın bulunmadığ ${ }^{63}$, (Tablo 1-4) bu durumun ise kadınların çeşitli nedenlerle oda başkanlığına seçilmediğini gösterdiği ileri sürülebilir. Diğer veteriner hekim odalarında kadınların oda başkanı olma durumları yapılacak çalışmalarla ortaya çıarılabilir.

Çeşitli tarihlerde Afyonkarahisar VHO tarafindan devlet bünyesinde veteriner hekimliğe daha özelleşmiş bir birimin kurulması talebinin pek çok kez devlet büyüklerine iletilmesinin, mesleği geliştirme çabası açısından önemli olduğu söylenebilir ${ }^{64}$.

Özen ve arkadaşları yapmış oldukları bir araştırmada (Özen ve ark. 2010) veteriner hekimlerin ilaç satış yetkisinin en olumsuz yönünün haksız rekabet olduğu tespit etmişlerdir Rekabet Kurulunun tebliği ile

\footnotetext{
${ }^{49}$ 1990-1992 dönemi yönetim kurulu çalışma raporu, 20/09/1992 tarihli genel kurul belgeleri. Afyonkarahisar VHO Arşivi.

${ }^{50}$ 1994-1996 dönemi yönetim kurulu çalışma raporu, 29/09/1996 tarihli genel kurul belgeleri. Afyonkarahisar VHO Arșivi.

${ }^{51} 01 / 10 / 2004$ tarih ve 26 nolu yönetim kurulu kararı. Afyonkarahisar VHO Arşivi. ${ }^{52} 01 / 08 / 2006$ tarih ve 70 noluyönetim kurulu kararı. Afyonkarahisar VHO Arşivi. ${ }^{53} 13 / 02 / 2006$ tarihli 396 sayılı gelen evrak. TVHB Arșivi.

${ }^{54} 26 / 12 / 2011$ tarih ve 90184 nolu gelen evrak. TVHB Arșivi.

${ }^{55} 02 / 01 / 2012$ tarih ve 0700/1338 nolu giden evrak. TVHB Arşivi.

${ }_{56}^{56} 18 / 06 / 2012$ tarih ve 2012-130 nolu gelen evrak. TVHB Arşivi.

${ }^{57} 25 / 12 / 2012$ tarih ve 2012-305 sayıli gelen evrak. TVHB Arşivi.

${ }^{58}$ 08/05/1997 tarih ve 9 nolu yönetim kurulu kararı. Afyonkarahisar VHO Arșivi.

${ }^{59} 22 / 07 / 2014$ tarih ve 14 nolu yönetim kurulu kararı. Afyonkarahisar VHO Arșivi.

${ }^{60} 10 / 04 / 2017$ tarih ve $303 / 177$ sayılı giden evrak. TVHB Arşivi.

${ }^{61}$ 20/06/2017 tarih ve 303/295 say1lı giden evrak.TVHB Arşivi.

${ }^{62} \mathrm{Bkz}$ : dipnot 8 .

${ }^{63}$ Bkz: dipnot 7

${ }^{64}$ Bkz: dipnot 46,49,50
} 
sonradan uygulamadan kalkmıs da olsa odanın 2003'te Afyonkarahisar Eczacılar Odası ile birlikte ilaç satıșı konusunda haksız rekabeti önlemek için düzenledikleri protokol ${ }^{65}$ Afyonkarahisar VHO'nun söz konusu sorunun çözümüne yönelik gayret göstermesi açısından olumlu olarak değerlendirilebilir. Samsun-Sinop VHO'da (Sanal ve Melikoğlu Gölcü 2014) ve Kars VHO'da (Kizlltepe 2017) veteriner hekimlere yönelik eğitim programlarının düzenlendiği benzer biçimde bu araştırmada Afyonkarahisar VHO'da da bu programların düzenlendiği ve bu eğitimlerin ise üyelerin mesleki bilgi ve becerilerinin gelişimi açısından olumlu faaliyetler olduğu ifade edilebilir.

Kars VHO'nun yayın organı olan derginin tarihi boyunca (1989-2017) sadece bir say1 yayınlandığ1 (Kiziltepe 2017), Afyonkarahisar VHO'nun ise tarihi boyunca (1968-2017) hiç yayın faaliyetinin bulunmadiğ ${ }^{66}$ bu durumun ise oda için bir eksiklik olduğu ileri sürülebilir.

Kızıltepe'nin tez çalışmasında (Kızıltepe 2010) Marmara Bölgesi ve Ege Bölgesinde çalışan serbest veteriner hekimlerle ilgili reklam yapma ve klinik açmadan çalışma ile ilgili deontolojik-etik ihlallere Türkiye'nin diğer bölgelerinden daha s1k rastlandığ1 Tong ve arkadaşlarının araştırmasında (Tong ve ark. 2014) İzmir VHO Haysiyet Divanının 1992-2014 yılları arasında 74 karar aldığ1. Afyonkarahisar VHO'da ise 1976-2018 ylları arasında beş disiplin vakasina rastlandığı bu durumun ise İzmir VHO ile kıyaslandığında görece düşük bir rakam olduğu ileri sürülebilir..

Sonuç olarak Afyonkarahisar VHO'nun tarihi gelişim sürecinde, saptanan eksiklikleri bir tarafa sorumluluk bölgesi özelinde mesleğin çıkarlarına ve mesleki sorunların çözümüne yönelik girişimleri ve yapmış olduğu eğitim çalıșmaları ile Türkiye'de veteriner hekimliği mesleğinin gelişimine ve dolayısı ile toplum sağlığına katkıda bulunduğu ifade edilebilir.

\section{KAYNAKLAR}

Kızıltepe, A. (2010). Türkiye'de Klinik Veteriner Hekimliği Uygulamalarında Karşılaşılan Deontolojik Etik Sorunlar Üzerine Bir Araștırma, Doktora Tezi, AÜ. Sağlık Bilimleri Enstitüsü, Ankara.

Kızıltepe, A. (2017). Türkiye'de Veteriner Hekim Odalarının Çalıșmalarına Yönelik Bir İnceleme: Kars Bölgesi Veteriner Hekimler Odası Örneği. Kafkas Univ Vet Fak Derg, 23: 757-765.

Melikogłu, B., Kızıltepe, A. (2008).Türk Veteriner Hekimleri Birliği: Tarihten Notlar. Türk Veteriner Hekimleri Birliği Dergisi, 1-2: 94-101.

Özen, A., Yüksel, E., Doğan, Ö. (2010) Veteriner İlaçları Satış Yetkisinin Veteriner Hekimliği Açısından Değerlendirilmesi: I. Klinisyenlerin Ilaç Satış Yetkisi Konusundaki Tutumlar1; Kafkas Univ Vet Fak
Derg,16, 805-812.

Sanal, S., Melikoglu Gölcü, B. (2014). Dünden bugüne Samsun-Sinop Bölgesi Veteriner Hekimler Odası. IV. Ulusal Veteriner Hekimliği Tarihi ve Mesleki Etik Sempozyumu Bildiriler Kitabı, Otak Form Ofset, Samsun.sf. 439-446.

Tong, E., Özdemir, H.G., Aslım, G. (2014). İzmir Veteriner Hekimler Odası Haysiyet Divanı kararlarının "gizliliğe sayg1 ilkesi" çerçevesinde değerlendirilmesi. Vet Hekim Der Derg,85: 35-41.

\footnotetext{
${ }^{65}$ Bkz: dipnot 32-34.

${ }^{66}$ Bkz: dipnot 8
} 